Situated learning and situated knowledge: gender, translating audiovisual adverts and professional responsibility

Dr Montse Corrius, Deparment of Communication, University of Vic, C/ Sagrada Família 7, 08500 Vic, Spain

Email: montse.corrius@uvic.cat

Tel: 003438861222

Dr Marcella De Marco, Faculty of Social Sciences and Humanities, London Metropolitan University, Calcutta House,

Old Castle Street, London E1 7NT, United Kingdom

Tel: (+ 44) 2073201175

Email: m.demarco@londonmet.ac.uk

Dr Eva Espasa (corresponding author)

Department of Translation, Interpretation and Applied

Languages, University of Vic, C/Laura, 1308500 Vic, Spain

Tel: 003438861222

Email: eva.espasa@uvic.cat 


\title{
Situated learning and situated knowledge: gender translating audiovisual adverts and professional responsibility
}

\author{
This article is aimed at building bridges between translation studies \\ and gender studies: we relate the concept of 'situated learning' in \\ translation, as a context-dependent approach through which learners \\ are exposed to real-life tasks, to the concept of 'situated \\ knowledges' from a feminist perspective. These concepts inspire our \\ teaching in that the curricular design of our courses is driven by \\ contextual factors and professional demands, not by what students \\ should know objectively. This article explores the varied situated \\ knowledge of students, trainers and professionals as regards gender \\ and professional priorities, as well as the way in which professional \\ responsibility is perceived. We examine students' and professionals' \\ attitudes to gender in advertising, through their responses to a \\ questionnaire. The main results show partial agreement about the \\ responsibility translators and advertisers have in the (re)production \\ of gender stereotypes, and an agreement about the importance of \\ including professional and ethical issues in education. This \\ underpins the need to develop tailored gender-related activities \\ across the curricula of translation and advertising courses. Our aim \\ is to show that the concept of situatedness can contribute to the \\ redefinition of syllabus design, the identification of pedagogical \\ goals and task planning.
}

Keywords: gender awareness; higher education; audiovisual advertising; audiovisual translation; situated learning; situated knowledge;

\section{Introduction}

This article presents an interdisciplinary and interuniversity study ${ }^{1}$ in which

\footnotetext{
${ }^{1}$ This research project was designed along with our dearest colleague Francesca Bartrina ( $\dagger$ ) from the University of Vic-UCC, to whom we fondly dedicate this
} 
we examine students' level of gender awareness in the analysis and translation of commercial and non-profit audiovisual advertising in a training context of situated learning. We focus on undergraduate and postgraduate students of Advertising and of Translation from London Metropolitan University (MA in Translation) and the University of Vic Central University of Catalonia (UVic-UCC) (Degree in Translation and Interpreting; Degree in Advertising and Public Relations). We have in mind the advertisers and audiovisual translators of tomorrow, i.e. the students of today. The research reported here is a follow-up to four previous phases and the results have been gathered during the period 2011-2014. We consider that our gendered perspective is appropriate for addressing the complexity of today's social phenomena and for the situatedness of all agents involved (including students, trainers and professionals).

This article explores the varied situated knowledge of students, trainers and professionals as regards gender and professional priorities. We also explore how their attitudes, self-image and sense of professional responsibility with respect to advertising and its translation may contribute to the redefinition of syllabus design, the identification of pedagogical goals and task planning. We have worked with the following materials:

1. A set of audiovisual advertisements, commercial and non-profit

2. A questionnaire for students

3. A questionnaire for translation and advertising professionals.

article. Her contribution and participation in this study was of utmost inspiration for us. 
This research is aimed at building bridges between translation studies and gender studies, creating a dialogue between the concepts of 'situated translation' and 'situated knowledges', which are discussed below.

\section{Situated translation and situated knowledges}

Kiraly (2000 and 2005) defends the use of 'situated translation' in translation training, and considers that situating learning implies an 'active involvement in authentic, experiential learning' (2000: 42-43). Kiraly places especial emphasis on authentic translations projects in class (2005). This is exemplified with a collaborative subtitling project Kiraly coordinated in his class, where students solved technical problems along with the client that had commissioned the project.

For Kiraly ‘situated translation' equals 'authentic translation', i.e. real-life professional assignments. In this sense, he follows the research by Risku (2002: 530-531), who defends including authentic - or nearly authentic - tasks in translation teaching. Risku's (524) theoretical framework is cognitive situated studies, and is also akin to systems theories and to poststructural and postmodernist approaches. Risku defends the dynamic nature of mental processes, a perspective which entails attention to social aspects. The assumption underlying this approach is that the question 'what happens in the translator's brain?' should be supplemented by others, such as 'What happens in the hands, in the computers, on the desks, in the languages, in the dialogues of translators?' (530).

Therefore, and following the research by Risku (2002), Kiraly considers translation as socially-situated praxis, which takes place in a specific physical and social environment. He proposes incorporating the 
professional context into the teaching context, where the student translator works together with other agents, where the translator's focus is on managing entire communicative situations and on 'a myriad of real-world factors including time pressure, professional responsibility, and selfassessment that would add real-world dimensions to otherwise lifeless exercises' (2005: 1103).

Risku (2002: 530) asks: 'where can we locate thought? What are the limits of the object of translation studies?' (our emphasis), and her answer is found in socially situated knowledge. For us, in accordance with this social approach, a way of going beyond the limits of the object of study is by exploring the possibilities of the subject, from the perspective of gender studies.

Consequently, here we would like to relate the concepts of 'situated translation' and 'situated learning' (as approaches which are dependent on the social context, where students are involved in authentic learning tasks), to the concept of 'situated knowledges', developed by Haraway in her work of 1988, seminal for feminism, 'Situated Knowledges: The Science Question in Feminism and the Privilege of Partial Perspective'.

For Haraway, objectivity can be challenged with the concept of situated knowledges. The use of the plural form in 'knowledges' in her essay is significant, since she believes that it is impossible to have an objective perspective. Only a partial vision is possible. She redefines objectivity in scientific research as 'particular and specific embodiment' (1988: 582). Haraway exemplifies her argument with the metaphor of vision for research and the situatedness that this encompasses: 
How to see? Where to see from? What limits to vision? What to see for? Whom to see with? Who gets to have more than one point of view? Who gets blinded? Who wears blinders? Who interprets the visual field? (587).

These questions are relevant for research as well as for our specific training contexts based on audiovisual materials. As we will see below, these are critically analysed in the classroom with a view to fostering social awareness and dialogue among students. Going back to Haraway (583):

Only partial perspective promises objective vision [...]. Feminist responsibility is about limited location and situated knowledge, not about transcendence and splitting of subject and object. It allows us to become answerable for what we learn how to see (our emphasis).

This emphasis on responsibility, constant in her writing and in feminist research, is parallel to the current emphasis on ethics in translation training, which calls for the translator's accountability. Baker and Maier (2011: 3) remind us that 'accountability means that [translators and interpreters] are increasingly held responsible for the consequences of their behaviour and therefore have to reflect carefully about how their decisions, both textual and non-textual, impact the lives of others'. This implies a crucial shift from professional to ethical responsibility. In this context, 'translators and interpreters have an ethical responsibility to the wider community and to humanity, over and above their responsibility to clients and authors' (7).

These concepts of situatedness inspire our teaching and research in that we always try to incorporate contextual factors and professional and ethical requirements, instead of 'disembodied and desituated' learning 
(Kiraly 2005: 1101). They are the general principles underlying our pedagogical approach, which is grounded in feminist pedagogies, and has specific implications for syllabus design, pedagogical goals and task planning, as will be shown below.

\section{Pedagogical Approach}

\subsection{Feminist Pedagogies}

Our situated approach falls within the tenets of feminist pedagogy, which, as Shrewsbury (1993: 14) has pointed out, 'has close ties with other liberatory pedagogies', and can be defined as follows:

Feminist pedagogy is a theory about the teaching/learning process that guides our choice of classroom practices by providing criteria to evaluate specific educational strategies and techniques in terms of the desired course goals and outcomes. These evaluative criteria include the extent to which a community of learners is empowered to act responsibly toward one another and the subject matter and to apply that learning to social action. (8)

For Shrewsbury (10), the pillars of feminist pedagogy are community, empowerment and leadership, which are similar to the features of feminist pedagogy as defined by Martel: participation and interaction, collaboration and cooperation, and engaged and passionate teaching, features which are also very inspiring for our teaching practices (Martel 1999 and Bartrina and Espasa 2012). Based on these principles, we aim to provide an atmosphere of freedom and creativity in which we can build on students' perceptions as creators and translators as well as consumers of advertisements. This requires an attitude that connects students and teachers, 
as well as an engaged approach to gender, advertising and translation, inherent in feminist and socioconstructivist pedagogies.

This engaged approach has been explored in feminist translation studies, for example by Arrojo (1995) and Maier (2003), who propose making explicit the teacher's commitment and approach in preparing and implementing curricula and syllabi. Maier (2003: 159) urges teachers to look for strategies 'to tantalize and challenge' students in order to promote their self-awareness.

Contemporary advertising provides plenty of opportunities for tantalising and challenging students. In this respect, in feminist studies Mills (1995) has explored the concept of 'multiple positions'. In any given advertisement, there are elements that make us feel uneasy and elements that make us feel pleasure. Even if we do not feel comfortable about how a text positions us as men or women, this text attracts us because there is information which seduces or challenges us (59). It is very inspiring to work on these aspects with students in the class. As translators, we are never addressed simply as men or as women: we are addressed in multiple ways and we have to find multiple positionings and negotiations.

\subsection{Syllabus Design}

The activities and questionnaire to which our students have been exposed in the present study are in line with the research which seeks to integrate ethical questions in the curriculum of translators' training. We support Gill and Guzmán’s (2011: 98) plea that 'learning translation cannot be understood only as acquiring techniques, technologies and levels of specialization [...]. It must also involve a social critique of the social 
conditions in which translation takes place'. They describe their experience in attempting to enrich their curriculum with activities and approaches which may enhance social awareness in translation teaching and see in the lack of these 'a symptom of a large social problem' (95). By asking our students to critically reflect upon the approach they use in translating and/or producing advertisements in which gender issues are at stake, we aim at the same objective. We link 'situated knowledge' with 'situated learning' as we confront our students with real-life situations that they will face in their career, thus enabling them to handle social challenges more confidently. In other words, we are 'training students to think through the consequences of their behaviour, rather than telling them what is right or wrong per se' (Baker and Maier 2011: 4).

\subsection{Pedagogical goals}

The pedagogical approach discussed in this section can be a determining factor in examining students' level of gender awareness in the analysis, creation and translation of commercial and non-profit audiovisual advertising in a training context of situated learning. Feminist pedagogies are at the base of the main learning objectives of the courses that the students who participated in this study were attending.

Although there are three different student groups (two from the field of Translation and one from the field of Advertising) and two different levels of education (undergraduate and postgraduate students), the lecturers share some of the pedagogical goals that can be considered from a gender perspective: 
- To raise gender awareness within the community of students who are receiving training to become (audiovisual) translators and/or advertisers.

- To instil in our students the habit of critical reflection upon the extent to which the marketing strategies used in audiovisual advertising campaigns continue to subtly perpetuate stereotypes about femininities and masculinities.

- To teach students to read advertisements critically to dismantle the injustice done by the images of women in the media because this is 'the most effective weapon to correct the effects of sexism in advertising' (Arconada 2009: 66).

- To promote creativity as a fundamental strategy in translation for advertising.

- To include translation as an essential part of a promotional campaign in an advertising agency.

The main objective of our study is, therefore, not only academic but also pedagogic, since it contributes to training. Finally, the lecturers all agree that it is our pedagogical responsibility to empower students by helping them develop greater gender awareness in the analysis, creation and translation of advertising. As Bartrina and Espasa (2012: 93) have put it, 'gender-related issues cannot be neglected any longer in the literature of our field. Contemporary advertising continually addresses gender issues and we, as translators and teachers of translation, cannot ignore such challenges'. And as stated by Gill and Guzmán (2011: 97) 'the academic setting can be a 
privileged space for achieving an understanding of what it is that we as translators understand to be our task'.

\subsection{Task planning}

Task planning has always been especially important in our academic settings and is integrated into the general syllabus design and definition of pedagogical goals (see González Davies 2003; Cánovas, González Davies and Keim 2009). In all groups the planning of tasks takes into account the professional context of their respective degrees. In the translation groups, therefore, the classroom becomes a virtual advertising agency, where translators and creative writers work together. Similarly, advertising students are familiar with strategies used in promoting products, and are aware of the role that translation can have in the internationalization of advertising campaigns.

Our aim is to create a dialogue between these professional constraints and ethical debates, as discussed above. This is why, when we design the teaching materials and assignments for our courses, gendersensitive texts and issues are included. We are aware that our identity affects our teaching discourses and practices, and that students' subjectivities are implicated in the process. As Perumal (2012: 69) states:

From their accounts we see that teachers often problematise the intersections and interactions between their identities with a view to creating educational environments conducive to educational goals. As a result their perceptions of their own identities, as well as their understandings of students' perceptions, impact on learning environment and pedagogic content. These identities are always fluctuating and contextually specific. 
Consequently, and in agreement with the proposals of Baker and Maier (2011: 6), we include tasks that promote critical and ethical awareness, such as debates, or translation tasks using authentic texts and briefs. With them, we are aware that assessment can be problematic when ethical dilemmas are involved, and value above all the quality of reasoning and reflection.

The translation tasks involved in our teaching include authentic commercials and non-profit advertisements (see Appendix 1), and simulated briefs that make students aware of their professional and ethical positions (see Appendix 2). We usually include materials proposed by our students, especially with reference to advertising campaigns that they have found engaging or provoking.

As the task descriptions show, our pedagogical approach includes both professional and ethical issues, which invites students to reflect on their responsibility in their work. How this reflection was articulated in this research is the focus of the following section.

\section{Methodology}

The present study adds a new dimension to the results gathered from the four previous research stages in which we 1) tested how students react to the representation and translation of gender issues in commercial advertising (in 2011); 2) examined the connections between feminist pedagogies and our courses on advertising translation (in 2012); 3) explored the extent to which the way we - trainers - correct and evaluate the students' activities may contribute to arousing a greater sensitivity towards the need to question the clichés and gender stereotypes sparked off through advertising (in 2012), 
and 4) examined whether students' choices in producing or translating nonprofit advertisements are different from the ones made when faced with commercial advertising campaigns (in 2013). Throughout this study, three student groups took part in the initial stages of the research and an additional group of professionals (Group 4) was involved in 2014. Of the students' groups, only group 3 was aware of their trainers' commitment to gender research, whereas the others (1 and 2$)$ were not.

In previous stages of research, students were asked to perform translation and reflective activities based on a set of commercial and nonprofit advertisements, which have been presented to contextualize this research (Appendices 1 and 2). For the analyses that we present here, all groups (students and professionals) answered a Likert-scale questionnaire, an instrument which has proved useful in the assessment of attitudes towards gender in learning contexts (see, e.g., García Pérez et al. 2010; Rebollo-Catalán et al. 2011).

\section{Group 1}

This group is comprised of 21 students enrolled in the Master in Translation at London Metropolitan University. This Master is open to 24 combinations of languages and is therefore taught to a very broad linguistic and cultural community. The majority of students do not speak English as their mother tongue. The module in which this gender-related study has been introduced is Subtitling, an optional subject offered in the second term after the completion of four compulsory subjects covering, among others, translation theory, the characteristics of applied translation (print advertising, amongst others) and the use of information technology. The 
study of gender is neither an integral part of the subject of subtitling nor of the curriculum of the Master. For this reason the lecturer gave a theoretical session on gender during the final week after the students had translated the aforementioned set of commercial and non-profit advertisements. The questionnaire was also administered in the final week, just before the lecturer delivered the theoretical presentation on gender and audiovisual translation. The native languages of the students of the three cohorts who took part in the study were French, Greek, Italian, Japanese, Polish, Portuguese, Russian and Spanish.

\section{Group 2}

This group is made up of 39 undergraduate students of Advertising and Public Relations of the UVic-UCC. The Undergraduate Course includes three subjects of English applied to these studies, given its prime importance for working in the fields of advertising and public relations. Apart from the competence in the language that students must acquire, they are taught various strategies that may be used in the preparation of an international campaign, though without special emphasis on any field of translation in particular. The questionnaire was given to first-year students three weeks before finishing the course, after they had learned to analyse an advertisement and a promotional campaign paying attention to both visual and auditory codes. The students responded to the questionnaire in Catalan or Spanish (whichever was their mother tongue). They carried out the translation of the advertisements prior to the questionnaire. 


\section{Group 3}

The context of group 3 is an Undergraduate Course in Translation and Interpretation of the UVic-UCC, which has included the subject of advertising translation since 1996. The 49 students of Group 3 translate from English into Catalan or Spanish. The subject is taught in the second year and is compulsory. The contents of the subject cover the translation of print advertising (5 weeks), audiovisual advertising ( 5 weeks) and comics and illustrated books (5 weeks).

A gender perspective is present throughout the selection of materials for translation in this subject. The students responded to the questionnaire in Spanish or Catalan a week before finishing their course, and the translation tasks were carried out previously.

\section{Group 4}

As mentioned above, in addition to the students of groups 1-3, advertising translators and advertising practitioners were also involved in this research. Forty-eight professionals answered a questionnaire online and they were reached by means of: 1) a number of Advertising and Translation agencies; 2) the Spanish Association of Advertising and Public Relations; 3) some professional mailing lists (in the fields of Translation and Advertising).

The questionnaire used in all the phases of this research can be seen as Appendix 3, below.

The participants in this study totalled 157 (109 students and 48 professionals). The sample distribution in the students' groups was the following: group $1=21$; group $2=39$; group $3=49$. It was generally 
homogeneous with the group of professionals, with the exception of group 1, which was comparatively smaller, because it involved an optional subject and depended on the availability of tutors for the many language combinations offered.

\section{Results and Discussion}

The foregoing section summarises the major findings of the questionnaire. Some insights into gender awareness and advertising in the light of the findings of the questionnaires are discussed. It is worth mentioning that the questionnaire was administered to the three students' groups in three different years (2011, 2012 or 2013) and to the professional group in 2014. Group 1: MA students in Translation -London Metropolitan; Group 2: BA students in Advertising - UVic-UCC; Group 3: BA students in Translation- UVic-UCC; Group 4: Professionals (see Methodology for further information about each group).

[Table 1 near here]

With regards to the statement about advertising reproducing gender stereotypes (see Table 1), only the group from the BA students in Translation (i.e. Group 3) seems to agree with it significantly, whereas there is more variation in the other two groups and even total disagreement from $10 \%$ of the Master's students. As far as professionals are concerned, the majority also agree with the statement and only $17 \%$ seem undecided. Interestingly, while the students of group 3 and the professionals seem to share a greater level of gender awareness, their responses partly differ too. This discrepancy might be a consequence of the fact that the students of group 3 had been previously, and more often, exposed to gender concerns 
than the students of groups 1 and 2, and to the practitioners whose daily work might not entail dealing with gender-related challenges.

[Table 2 near here]

The responses about professional practice and gender stereotypes in advertising are even more varied (see Table 2). Around 20\% of Advertising students and Master's students do not agree that their professional practice can contribute to perpetuating gender stereotypes and only a minority (circa $27 \%$ ) from group 3 totally agrees with this statement. In the case of professionals $40 \%$ do not agree with it, while only $29 \%$ agree with it. It is difficult to interpret the reasons behind these different responses, but the answer may lie in the substantial percentage reflecting indecisiveness spread across the study groups. It is common to think that indecisiveness denotes unwillingness or inability to take a position on a matter. In this case, it might actually demonstrate that people are not accustomed to reflect that the roles and duties they perform in their work environment may have a longterm, social impact on their own lives. It could be argued that developing the habit of thinking critically about professional responsibilities in the educational years is essential to build up a more balanced, and therefore healthier, society. [Table 3 near here]

The data presented in Table 3 indicate that Advertising students feel that as professionals they have responsibility for the transmission of gender stereotypes (67\% of the Advertising students agree with this statement and only $13 \%$ show some degree of disagreement). The students from the other three groups show a mild level of agreement to this statement or even some 
notable disagreement (47\% of the Master's group). Professionals' responses are quite divergent as they range over complete disagreement, slight disagreement, indecisiveness, partial agreement and total agreement (the percentages are very similar, around $20 \%$ per level of agreement). Once again, there is no consistent agreement about the individuals' responsibilities in matters of gender issues and about how these may be tackled in practice. This suggests that a gender-focused approach in educational curricula and work policies might be called for. This study is a step forward towards this target.

[Table 4 near here]

Many students think that gender is as important as other professional priorities (49\% of the Master's students, $37 \%$ of the Advertising students and $44 \%$ of the undergraduate students of translation; see Table 4). However, the opinions range over all levels of agreement and disagreement. Again, as with the previous statement, the professionals' results are quite divergent, as they range over complete disagreement, slight disagreement, indecisiveness, partial agreement and total agreement. However, it is surprising that only $33 \%$ of professionals consider gender as important as other professional priorities. Apparently, they consider other issues more fundamental, but this does not necessarily mean that they claim that gender issues are unimportant and should be neglected. Therefore, including ethical debates in the classroom as discussed above, and designing gender-sensitive materials and assignments for our courses, would help students acquire awareness about the relevance of both professional and gender-related priorities ones in their working environment. 
[Table 5 near here]

The majority of students tend to partially or totally agree about the importance of developing awareness of gender issues in the educational years (see Table 5). Thus, they probably understand that the training they receive in class is also 'a process by which people acquire the habits and skills necessary to participate and act in their society' (De Marco 2011: 152). Similarly, practitioners mostly agree with the statement (67\%). [Table 6 near here] No student group totally disagrees with the statement that advertising must not use sexist language, and the great majority tend to a partial or total agreement. Again, students' and professionals' results are similar. What is puzzling is the fact that the answers provided here by Master's and Advertising students (groups 1 and 2) differ slightly from those to statement $\mathrm{G}$ (see data in Table 7). In other words, there are more students who believe that advertising must not use sexist language than students who think that advertising must not produce sexist ads (group 1: $71 \%$ versus $47 \%$; group 2: $87 \%$ versus $66 \%$ ). It seems that for them language is more noticeable and therefore more open to criticism than the adverts in general, as far as sexism is concerned.

[Table 7 near here]

Table 7 indicates that there is an overwhelming tendency to (partially or totally) agree with the statement that advertising must not produce sexist adverts, particularly among the Translation undergraduates from the UVic UCC. Nevertheless, there are a number of students who do not seem to be very concerned about sexism in advertising because most of the Master's 
students (53\%) and 34\% of Advertising students showed partial disagreement or indecisiveness to the statement. In this respect it should be reiterated that the students from group 3 knew their teachers' commitment to gender politics, while students from groups 1 and 2 were unaware of it when they answered the questionnaire. From this, it might be inferred that the fact of knowing their teachers' commitment might have influenced the responses of group 3, as opposed to those of students belonging to institutional environments where gender is not perceived as an issue.

Professionals also agree with this statement and they seem very coherent in their responses and practice in so far as the results from questions $\mathrm{F}$ (advertising must not use sexist language) and $\mathrm{G}$ (advertising must not produce sexist ads) are almost identical: $84 \%$ partially or totally agree with statement $\mathrm{F}$ and $82 \%$ with statement $\mathrm{G}$.

Finally, we would like to add that Haraway's (1988) constant emphasis on responsibility and the current emphasis on ethics in translation made clear by Baker and Maier (2011) made us consider the possibility of including in the practitioners' questionnaire a second part with specific questions about their awareness of, and familiarity with, the laws, rules and code of ethics that regulate advertising contents. The questions included are the following:

1. Do you know any advertising campaign or commercial that reproduces sexist stereotypes, which might have led to sexist, racial, employment, or disability discrimination or which might have negatively affected any particular group? 
If you have answered yes, could you enumerate a maximum of 5 examples?

2. Are you aware of the existence of the laws, rules and code of ethics that regulate advertising contents in this field?

3. Are you familiar with them and do you regularly check them in your profession?

It is worth mentioning that $67 \%$ of the respondents answered affirmatively to question 1, which confirms that sexist stereotypes still appear in some advertisements, particularly with the aim of selling a wide variety of products such as detergents, cars, beauty products, perfumes, clothes and even some food - as can be inferred from the examples provided by respondents, which will be incorporated into the class discussions in our future courses. Although the presence of sexist adverts nowadays might seem obvious, we find it important to include the respondents' opinion on this, and with reference to specific advertisements. In a context of postfeminism, and ostensible equality, younger generations of students and professionals do not always seem to be aware of pervading sexism. Surprisingly, less than $50 \%$ of professionals are aware of the existence of laws, regulations and a code of ethics that regulate advertising in this field (43\%), and what is more, the percentage is still lower when we focus on those who are familiar with such laws, regulations and code of ethics and if they check them regularly in their profession (only 25\%). Hence, $75 \%$ of professionals are unaware of or ignore the present regulations, which means that, on occasion, advertising and translations 
might contravene the law. This reinforces the need to include legal, as well as ethical and deontological aspects in our courses.

\section{Conclusions and ways forward}

This research has intended to bridge the fields of socioconstructivist translator training and gender pedagogies. It has contributed to a debate on the concepts of situated translation, situated learning and situated knowledges, and the points they have in common, such as the agency of the subjects involved, as well as their professional and ethical responsibility.

The social situation has specific implications for syllabus design, pedagogical goals and task planning, where both professional issues and ethical matters need to be explicitly addressed. Research was designed to explore students' gender awareness (as a possible site of conflict between ethics and profession), and a questionnaire was distributed among different groups of translation and advertising students, in order to discover how their respective situatedness affected their professional and social perspectives.

The results show that proportionately more of the translation students found gender criteria as important as any other professional criteria compared with the advertising students. The attention to ethical and gender issues (especially in group 3) cannot be separated from the trainers' specific gender commitment to gender politics, even though the questionnaires were anonymous. We cannot exclude students' pressure when their tasks are evaluated and we might even wonder whether it is positive that students' response is affected by the lecturers' overt commitment to gender concerns. In order to further examine the gender awareness of students, it will be 
useful to examine their preferences in the long term when institutional pressure has disappeared. It was curious to note how students distinguished between sexist language - which was generally criticised - and sexist advertisements - which were not so generally rejected - particularly among BA Advertising and MA translation students (groups 2 and 1 respectively). This might show that for them language is more important than the advert in general, or that sexist language is more overt, easier to pinpoint or criticize than sexism in adverts, which is often covert and ambivalent in contemporary advertising. However, when we examine the students' translations, which were analysed in other stages of this research, we realize that it is difficult for them to avoid the generic masculine, which is consistent with the marginal use of inclusive language in professional contexts. Practitioners, though, do not distinguish between sexist language and sexist advertisements. Their results in these two questions ( $F$ and $G$ ) are almost identical.

The inclusion of a group of professional translators and advertisers in addition to students in this study was especially enriching in that it showed more diverse responses towards professional and ethical matters. Moreover, common to all groups was an agreement about the importance of including professional and ethical issues in education. The conclusions of this research are tentative, but the general tendencies detected from our analysis will be explored in further research. In future, we will consider expanding the groups involved, as well as engaging all the agents in the pedagogical and professional aspects relevant for this research. 
To conclude, a more systematic and widely spread use of specially tailored gender-related activities across the curricula of translation and advertising courses would certainly help in achieving the goal of enhancing the students' awareness, reflection and initiative with regards to the social implications of their role as mediators of messages and values. Baker and Maier (2011) describe activities such as classroom debates, critical essays and role plays as a valuable framework for the achievement of this goal. The activities and questionnaires described in this study have been experimental pedagogical tools which have also had promising outcomes. However, it is sometimes difficult to handle these tools in scholarly and didactic contexts where training with the purpose of instilling a gender-ethical approach is often not considered to be worthwhile. We believe that translating, and teaching translation from a 'situated' self-aware perspective, provides students with the knowledge they need to live future experiences which may 'become $[\ldots]$ vehicles of social agency, i.e. a political voice, a means to engage with the complexity of a community - with the inevitable unequal structures of power' (Gill and Guzmán 2011: 100).

\section{Acknowledgements}

The authors would like to thank Ruben Giró for his help in the design of the questionnaire; Oreste Attardi for providing assessment and information about advertising agencies; Santiago Jordán for providing information about advertisers' addresses; Jaume-Miquel March for his advice with cognitive validation of the questionnaire, and Jorge Díaz-Cintas for helping distribute the questionnaire.

References 
Arconada, Miguel Ángel (2009) 'La publicitat i les trampes per a la igualtat. Estereotips femenins en els anuncis'. Proceedings of the seminar Estereotips en la imatge de les dones al món educatiu i als mitjans de comunicació, by Sindicat de Treballadores i Treballadors Intersindical (STEI-i), Associació Dones Educadores de les Illes Balears. Internal publication.

Arrojo, Rosemary, 1995. 'Postmodernism and the teaching of translation', in Cay Dollerup and Vibeke Appel (eds) Teaching Translation and Interpreting 3: New Horizons. Papers from the Third Language International Conference 1995, Amsterdam and Philadelphia: John Benjamins, 98-103.

Baker, Mona and Carol Maier (2011) 'Ethics in Interpreter \& Translator Training', The Interpreter and Translator Trainer 5 (1): 1-14. doi:10.1080/13556509.2011.10798809.

Bartrina, Francesca and Eva Espasa (2012) 'Evaluating Creativity from a Perspective of Feminist Pedagogies: Translating Print Advertisements in the Virtual Classroom', in Marcos Cánovas, Gemma Delgar, Lucrecia Keim, Sarah Kahan and Àngels Pinyana (eds) Challenges in Language and Translation Teaching in the Web 2.0 Era, Granada: Comares, 93-104.

Cánovas, Marcos, María González Davies, Lucrecia Keim (eds) (2009) Acortar Distancias. Las TIC en la clase de traducción y de lenguas extranjeras, Barcelona: Octaedro.

De Marco, Marcella (2011) 'Bringing gender into the subtitling classroom', in Laura Incalcaterra McLoughlin, Marie Biscio and Máire Áne Ní Mhainnín (eds) Audiovisual Translation: Subtitles and Subtitling. Theory and Foreign Language Practice. New York, Berlin, Bruxelles, Frankfurt am Main, Oxford, Wien: Peter Lang, 139-155. García Pérez, Rafael, M. Ángeles Rebollo Catalán, Olga Buzón García, Ramón González-Piñal, Raquel Barragán Sánchez and Estrella Ruiz Pinto (2010) 'Actitudes del alumnado hacia la igualdad de género', Revista de Investigación Educativa, 28(1), 217-232. Available at: http://revistas.um.es/rie/article/view/98951. Last accessed: 9 March 2015. 
Gill, Rosalind M. and María Constanza Guzmán (2011) 'Teaching Translation for Social Awareness in Toronto', The Interpreter and Translator Trainer 5 (1): 93-108. doi:10.1080/13556509.2011.10798813.

González Davies, María (ed) (2003) Secuencias: Tareas para el aprendizaje interactivo de la traducción especializada, Barcelona: Octaedro.

Haraway, Donna J. (1988) 'Situated Knowledges: The Science Question in Feminism and the Privilege of Partial Perspective', Feminist Studies 14(3): 575-599.

Kiraly, Don (2000) A Social Constructivist Approach to Translator Education: Empowerment from Theory to Practice, Manchester, UK: St. Jerome Publishing.

-- (2005) 'Project-Based Learning: A Case for Situated Translation', Meta: journal des traducteurs / Meta: Translators' Journal 50 (4): 10981111. doi:10.7202/012063ar.

Maier, Carol S. (2003) 'Gender, Pedagogy, and Literary Translation', in Brian James Baer and Geoffrey S. Koby, ATA. Beyond the Ivory Tower: Rethinking Translation Pedagogy, Amsterdam and Philadelphia: John Benjamins Publishing, 157-169.

Martel, Angeline (1999) 'Intervenciones pedagógicas en favor de niñas y mujeres brillantes', in Julie L. Ellis and John Willinsky (eds) Niñas, mujeres y superdotación. Un desafío a la discriminación educativa de las mujeres (Trans. Pablo Villadangos), Madrid: Narcea, S.A. de Ediciones, 79-97.

Mills, Sara (1995) Feminist Stylistics, London and New York: Routledge. Perumal, Juliet Christine (2012) 'Bodies as Objects of Pedagogic Power Relations', Gender and Education, 24 (1): 57-71. doi:10.1080/09540253.2011.571662

Rebollo-Catalán, Ma Ángeles, Rafael García Pérez, Joaquín Piedra, and Luisa Vega (2011) 'Diagnóstico de la cultura de género en educación: actitudes del profesorado hacia la igualdad', Revista de Educación, (355), 219-220.doi: 10-4438/1988-592X-RE-2010-355035 . 
Risku, Hanna (2002): 'Situatedness in Translation Studies', Cognitive Systems Research 3: 523-533.

Shrewsbury, Carolyn M. (1993) 'What is Feminist Pedagogy?', Women's Studies Quarterly 21 (3-4) (Fall-Winter): 8-16.

\section{Appendices}

\section{Audiovisual advertisements, commercial and non-profit, used} by all groups of students

Year 2011: L'Oréal Elvive 'Because I'm Worth it' starring Jennifer Aniston (1997), L'Oréal 'Because You're Worth it' starring Kerry Washington (2008), and the three campaigns used in the UK and in Italy in the years 2007-2009 to advertise Müller yogurt.

Year 2012: Miller Lite - Second Unmanly Thing (2011), Miller Lite - You were Offside (2011).

Year 2013: Domestic Violence PSA (2008), One Water (2010), What will you feel (2008).

\section{Instructions for students' translation tasks in the respective} courses

\section{Group 1 (Translation MA students, London Metropolitan)}

Please subtitle the following advertisements ${ }^{2}$ into your own language paying special attention to:

1) the interaction between images and soundtrack and

\footnotetext{
${ }^{2}$ See Appendix 1 above for information on the advertisements used in our courses.
} 
2) the effect of this interaction on the perception of gender as represented on the screen.

Group 2 (Advertising undergraduate students, UVic-UCC)

Imagine that you are working for an International Advertising Agency. You have been asked to translate into Catalan the following advertisements (see note 1 ):

The advertising agency wants you to pay special attention to the perception of gender as represented on the screen.

Read the background information about the company and the brand before carrying out the translation.

\section{Group 3 (Translation undergraduate students, UVic-UCC)}

[X company /organisation + context $]$ will soon be established in Europe, with promotional campaigns distributed through the Internet. On the Spanish and Catalan webpages, the advertisements will be dubbed. For this reason, the dubbing studio you work for has commissioned a lip-synch of their ads.

We recommend that you pay special attention to gender stereotypes (i. e. generalizations that may lead to sexist, racial or work discrimination).

\section{Questionnaire about gender and advertising}

\section{QUESTIONNAIRE}

\section{Gender:}

Female

$\square$ Male

Age:

Nationality: 


\section{Country of residence:}

\section{Ethnicity:}

Express your agreement/disagreement with the following statements

(1: I disagree completely with this statement; 2: I disagree partially with this statement; 3: I neither agree nor disagree with this statement; 4: I partially agree with this statement; 5: I completely agree with this statement)

a) Advertising reproduces gender stereotypes (i.e. generalisations which potentially lead to sexist, homophobic, racial, or employment discrimination).

b) My professional practice may contribute to perpetuating gender stereotypes in advertising.

c) In my profession I have responsibility for whether or not gender stereotypes are transmitted.

d) In my profession, gender priorities are as important as other professional priorities.

e) Developing knowledge about gender issues during the educational years will help me develop my professional ethics.

f) Advertising must not use sexist language.

g) Advertising must not produce sexist ads. 


\section{Tables}

Table 1: Responses by group to the question about gender stereotypes

\begin{tabular}{|l|l|l|l|l|}
\hline $\begin{array}{l}\text { Level of } \\
\text { agreement }\end{array}$ & $\begin{array}{l}\text { Group 1 MA } \\
\text { Translation } \\
\text { London Met }\end{array}$ & $\begin{array}{l}\text { Group 2 BA } \\
\text { Advertising } \\
\text { UVic-UCC }\end{array}$ & $\begin{array}{l}\text { Group 3 BA } \\
\text { Translation } \\
\text { UVic-UCC }\end{array}$ & Group 4 \\
Professionals \\
\hline $\begin{array}{l}\mathbf{1} \text { complete } \\
\text { disagreement }\end{array}$ & $10 \%$ & $0 \%$ & $0 \%$ & $8 \%$ \\
\hline $\begin{array}{l}\text { 2 partial } \\
\text { disagreement }\end{array}$ & $15 \%$ & $11 \%$ & $2 \%$ & $8 \%$ \\
\hline $\begin{array}{l}\mathbf{3} \\
\text { indecisiveness }\end{array}$ & $15 \%$ & $21 \%$ & $2 \%$ & $17 \%$ \\
\hline $\begin{array}{l}\mathbf{4} \text { partial } \\
\text { agreement }\end{array}$ & $\mathbf{5 0 \%}$ & $\mathbf{5 5 \%}$ & $47 \%$ & $31 \%$ \\
\hline $\begin{array}{l}\text { 5 complete } \\
\text { agreement }\end{array}$ & $10 \%$ & $13 \%$ & $\mathbf{4 9 \%}$ & $\mathbf{3 6 \%}$ \\
\hline & & & \\
\hline
\end{tabular}


Table 2. Responses by group to the question about professional practice and gender stereotypes

\begin{tabular}{|l|l|l|l|l|}
\hline $\begin{array}{l}\text { Level of } \\
\text { agreement }\end{array}$ & $\begin{array}{l}\text { Group 1 MA } \\
\text { Translation } \\
\text { London Met }\end{array}$ & $\begin{array}{l}\text { Group 2 BA } \\
\text { Advertising } \\
\text { UVic-UCC }\end{array}$ & $\begin{array}{l}\text { Group 3 BA } \\
\text { Translation } \\
\text { UVic-UCC }\end{array}$ & $\begin{array}{l}\text { Group 4 } \\
\text { Professionals }\end{array}$ \\
\hline $\begin{array}{l}\mathbf{1} \text { complete } \\
\text { disagreement }\end{array}$ & $7 \%$ & $5 \%$ & $12 \%$ & $23 \%$ \\
\hline $\begin{array}{l}\mathbf{2} \text { partial } \\
\text { disagreement }\end{array}$ & $12 \%$ & $10 \%$ & $8 \%$ & $17 \%$ \\
\hline $\mathbf{3}$ & $38 \%$ & $\mathbf{4 9 \%}$ & $\mathbf{2 9 \%}$ & $\mathbf{3 1 \%}$ \\
\hline indecisiveness & $\mathbf{4 3 \%}$ & $26 \%$ & $24 \%$ & $23 \%$ \\
\hline $\mathbf{4}$ partial \\
agreement
\end{tabular}


Table 3 Responses by group to the question about professional responsibility and gender stereotypes

\begin{tabular}{|l|l|l|l|l|}
\hline $\begin{array}{l}\text { Level of } \\
\text { agreement }\end{array}$ & $\begin{array}{l}\text { Group 1 MA } \\
\text { Translation } \\
\text { London Met }\end{array}$ & $\begin{array}{l}\text { Group 2 BA } \\
\text { Advertising } \\
\text { UVic-UCC }\end{array}$ & $\begin{array}{l}\text { Group 3 BA } \\
\text { Translation } \\
\text { UVic-UCC }\end{array}$ & $\begin{array}{l}\text { Group 4 } \\
\text { Professionals }\end{array}$ \\
\hline $\begin{array}{l}\mathbf{1} \text { complete } \\
\text { disagreement }\end{array}$ & $19 \%$ & $9 \%$ & $2 \%$ & $18 \%$ \\
\hline $\begin{array}{l}\mathbf{2} \text { partial } \\
\text { disagreement }\end{array}$ & $\mathbf{2 8 \%}$ & $4 \%$ & $16 \%$ & $17 \%$ \\
\hline $\begin{array}{l}\mathbf{3} \\
\text { indecisivenes } \\
\text { s }\end{array}$ & $22 \%$ & $20 \%$ & $\mathbf{3 4 \%}$ & $\mathbf{2 5 \%}$ \\
\hline $\begin{array}{l}\mathbf{4} \text { partial } \\
\text { agreement }\end{array}$ & $\mathbf{2 8 \%}$ & $\mathbf{4 4 \%}$ & $21 \%$ & $23 \%$ \\
\hline $\begin{array}{l}\mathbf{5} \text { complete } \\
\text { agreement }\end{array}$ & $3 \%$ & $23 \%$ & $27 \%$ & $17 \%$ \\
\hline & & & & \\
\hline $\begin{array}{l}\text { c) In my profession I have responsibility for whether or not gender stereotypes } \\
\text { are transmitted. }\end{array}$ & & &
\end{tabular}


Table 4 Responses by group to the question about gender and other professional priorities

\begin{tabular}{|l|l|l|l|l|}
\hline $\begin{array}{l}\text { Level of } \\
\text { agreement }\end{array}$ & $\begin{array}{l}\text { Group 1 MA } \\
\text { Translation } \\
\text { London Met }\end{array}$ & $\begin{array}{l}\text { Group 2 BA } \\
\text { Advertising } \\
\text { UVic-UCC }\end{array}$ & $\begin{array}{l}\text { Group 3 BA } \\
\text { Translation } \\
\text { UVic-UCC }\end{array}$ & $\begin{array}{l}\text { Group 4 } \\
\text { Professionals }\end{array}$ \\
\hline $\begin{array}{l}\mathbf{1} \text { complete } \\
\text { disagreement }\end{array}$ & $0 \%$ & $10 \%$ & $4 \%$ & $23 \%$ \\
\hline $\begin{array}{l}\text { 2 partial } \\
\text { disagreement }\end{array}$ & $31 \%$ & $17 \%$ & $10 \%$ & $17 \%$ \\
\hline $\begin{array}{l}\mathbf{3} \\
\text { indecisivenes } \\
\text { s }\end{array}$ & $20 \%$ & $\mathbf{3 6 \%}$ & $\mathbf{4 2 \%}$ & $27 \%$ \\
\hline $\begin{array}{l}\mathbf{4} \text { partial } \\
\text { agreement }\end{array}$ & $\mathbf{4 6 \%}$ & $24 \%$ & $33 \%$ & $14 \%$ \\
\hline $\begin{array}{l}\mathbf{5} \text { complete } \\
\text { agreement }\end{array}$ & $3 \%$ & $13 \%$ & $11 \%$ & $19 \%$ \\
\hline & & & & \\
\hline d) In my profession, gender priorities are as important as other professional \\
priorities.
\end{tabular}


Table 5 Responses by group to the question about gender issues and education

\begin{tabular}{|c|c|c|c|c|}
\hline $\begin{array}{l}\text { Level of } \\
\text { agreement }\end{array}$ & $\begin{array}{l}\text { Group } 1 \text { MA } \\
\text { Translation } \\
\text { London Met }\end{array}$ & $\begin{array}{l}\text { Group } 2 \text { BA } \\
\text { Advertising } \\
\text { UVic-UCC }\end{array}$ & $\begin{array}{l}\text { Group } 3 \text { BA } \\
\text { Translation } \\
\text { UVic-UCC }\end{array}$ & $\begin{array}{l}\text { Group } 4 \\
\text { Professionals }\end{array}$ \\
\hline $\begin{array}{l}1 \text { complete } \\
\text { disagreement }\end{array}$ & $0 \%$ & $4 \%$ & $0 \%$ & $6 \%$ \\
\hline $\begin{array}{l}2 \text { partial } \\
\text { disagreement }\end{array}$ & $0 \%$ & $6 \%$ & $4 \%$ & $4 \%$ \\
\hline $\begin{array}{l}3 \\
\text { indecisiveness }\end{array}$ & $12 \%$ & $24 \%$ & $14 \%$ & $23 \%$ \\
\hline $\begin{array}{l}4 \text { partial } \\
\text { agreement }\end{array}$ & $48 \%$ & $36 \%$ & $35 \%$ & $23 \%$ \\
\hline $\begin{array}{l}5 \text { complete } \\
\text { agreement }\end{array}$ & $40 \%$ & $30 \%$ & $47 \%$ & $44 \%$ \\
\hline
\end{tabular}


Table 6 Responses by group to the question advertising and sexist language

\begin{tabular}{|l|l|l|l|l|}
\hline $\begin{array}{l}\text { Level of } \\
\text { agreement }\end{array}$ & $\begin{array}{l}\text { Group 1 MA } \\
\text { Translation } \\
\text { London Met }\end{array}$ & $\begin{array}{l}\text { Group 2 BA } \\
\text { Advertising } \\
\text { UVic-UCC }\end{array}$ & $\begin{array}{l}\text { Group 3 BA } \\
\text { Translation } \\
\text { UVic-UCC }\end{array}$ & $\begin{array}{l}\text { Group 4 } \\
\text { Professionals }\end{array}$ \\
\hline $\begin{array}{l}\text { 1 complete } \\
\text { disagreement }\end{array}$ & $0 \%$ & $0 \%$ & $0 \%$ & $8 \%$ \\
\hline $\begin{array}{l}\text { 2 partial } \\
\text { disagreement }\end{array}$ & $10 \%$ & $8 \%$ & $4 \%$ & $2 \%$ \\
\hline $\mathbf{3}$ \\
indecisivenes \\
s & $19 \%$ & $5 \%$ & $12 \%$ & $6 \%$ \\
\hline $\begin{array}{l}\mathbf{4} \text { partial } \\
\text { agreement }\end{array}$ & $24 \%$ & $23 \%$ & $16 \%$ & $19 \%$ \\
\hline $\begin{array}{l}\mathbf{5} \text { complete } \\
\text { agreement }\end{array}$ & $\mathbf{4 7 \%}$ & $\mathbf{6 4 \%}$ & $\mathbf{6 8 \%}$ & $\mathbf{6 5 \%}$ \\
\hline & & & & \\
\hline f) Advertising must not use sexist language. & & \\
\hline
\end{tabular}


Table 7 Responses by group to the question about sexist adverts

\begin{tabular}{|l|l|l|l|l|}
\hline $\begin{array}{l}\text { Level of } \\
\text { agreement }\end{array}$ & $\begin{array}{l}\text { Group 1 MA } \\
\text { Translation } \\
\text { London Met }\end{array}$ & $\begin{array}{l}\text { Group 2 BA } \\
\text { Advertising } \\
\text { UVic-UCC }\end{array}$ & $\begin{array}{l}\text { Group 3 BA } \\
\text { Translation } \\
\text { UVic-UCC }\end{array}$ & $\begin{array}{l}\text { Group 4 } \\
\text { Professionals }\end{array}$ \\
\hline $\begin{array}{l}\mathbf{1} \text { complete } \\
\text { disagreement }\end{array}$ & $0 \%$ & $0 \%$ & $4 \%$ & $8 \%$ \\
\hline $\begin{array}{l}\mathbf{2} \text { partial } \\
\text { disagreement }\end{array}$ & $28 \%$ & $20 \%$ & $2 \%$ & $4 \%$ \\
\hline $\mathbf{3}$ & $25 \%$ & $14 \%$ & $8 \%$ & $6 \%$ \\
\hline $\begin{array}{l}\text { indecisivenes } \\
\text { s }\end{array}$ & $10 \%$ & $17 \%$ & $19 \%$ & $17 \%$ \\
\hline $\begin{array}{l}\mathbf{4} \text { partial } \\
\text { agreement }\end{array}$ & & $\mathbf{4 9 \%}$ & $\mathbf{6 7 \%}$ & $\mathbf{6 5 \%}$ \\
\hline $\begin{array}{l}\mathbf{5} \text { complete } \\
\text { agreement }\end{array}$ & $\mathbf{3 7 \%}$ & & & \\
\hline & & & & \\
\hline g) Advertising must not produce sexist ads. & &
\end{tabular}


